\title{
JUURNAL.RU
}

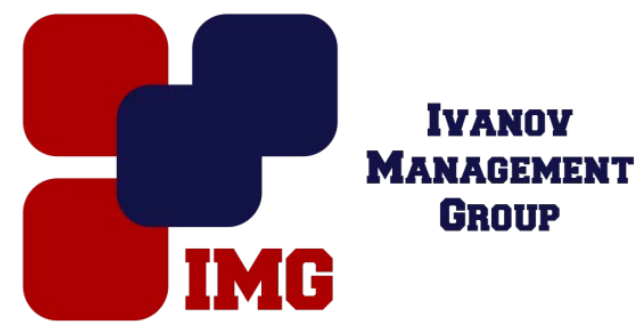

Кузнецова С.Ю.

Чувашский государственный университет им. И.Н.Ульянова

Чебоксары, Россия

doi: 10.18411/lj-30-11-2016-4-07

idsp 000001:lj-30-11-2016-4-07

\section{Систематизация факторов воспроизводства трудового потенциала предприятия}

\section{Аннотация}

В статье, обобщив и изучив научные взгляды ученых-экономистов, предложено систематизировать факторы, влияющие на воспроизводство трудового потенциала предприятия по двойному признаку: по среде существования на внешние и внутренние, по составляющим воспроизводства на натуральные, стоимостные, социальные.

Ключевые слова: трудовой потенциал, воспроизводство, факторы.

Воспроизводство трудового потенциала является одной из самых актуальных и сложных проблем науки и практики управления. Данная проблема на разных уровнях уже в течение нескольких десятков лет изучается зарубежными и отечественными учеными различных отраслей науки.

Большое значение для управления воспроизводством трудового потенциала имеет систематизация факторов, позволяющих регулировать воспроизводство на всех уровнях и этапах производственного процесса и выделять в случае негативных изменений движущие силы, которые способствовали бы улучшению ситуации. Поэтому четкое представление о факторах, которые действуют в данном конкретном случае, позволят вовремя и эффективно контролировать процесс воспроизводства на всех этапах, что в конечном результате существенно повысит уровень производства.

В целом, под фактором понимают «условие, движущую силу, причину любого процесса, который определяет его характер или одну из основных черт» [2]. Следовательно, относительно факторов, влияющих на воспроизводство трудового потенциала, можно говорить, что это условие, причина изменения исходного состояния, которое определяет его последующее развитие. 
Обобщив и изучив научные взгляды ученых-экономистов, мы пришли к выводу, что существует несколько подходов к классификации факторов, влияющих на воспроизводство трудового потенциала [1; 3; 4].

1. При рассмотрении трудового потенциала как совокупности физических, интеллектуальных и социальных способностей человека или какой-то общности людей, все факторы, влияющие на его формирование можно условно разделить на три укрупненные группы: природно-климатические, социально-экономические, демографические.

2. Также имеется классификация факторов, влияющих на воспроизводство трудового потенциала, в зависимости от уровня:

- на макрорегиональном уровне: экономическая и социальная политика; в современных условиях - коренное изменение системы управления и прежде всего перераспределение функций между центром и регионами, развитие различных форм собственности и занятости;

- на уровне организации: особенности организации труда и процессов управления персоналом, научно- технические и культурные факторы;

- на уровне работника: психофизиологические особенности и социально-демографический статус, образование, опыт, личностные характеристики.

3. Факторы подразделены на две основные группы: относящиеся к воспроизводству потенциала работников (а также безработных, которые реально предъявляют спрос на занятость) в процессе трудовой деятельности и формирующие трудовой потенциал вне участия в производстве. Такой подход позволяет изучать, насколько эффективно воздействуют факторы первой группы на воспроизводство используемых трудовых ресурсов и какие требования к факторам второй группы приоритетны для производственной деятельности.

4. По источникам образования факторы, влияющие на воспроизводство трудового потенциала, классифицируются, как внешние и внутренние относительно предприятия, по природе происхождения - факторы организационно-управленческие, техникотехнологические, экономические, социально-психологические, профессионально-квалификационные и т.п.

Наиболее распространенной классификацией, позволяющей максимально точно осветить все стороны воспроизводства трудового потенциала предприятия является деление факторов на внешние и внутренние относительно предприятия. Воспроизводство трудового потенциала предприятия - это сложный процесс, на который влияют множество разнообразных факторов. С целью их наибольшего учета и повышения эффективности воспроизводства трудового потенциала 
предприятия необходимо сгруппировать все факторы по признаку их принадлежности к определенной стороне процесса воспроизводства.

Придерживаясь предложенного автором трехаспектного подхода к определению сущности воспроизводства трудового потенциала предприятия [5], автор считает целесообразным предложить группировку факторов, влияющих на воспроизводство трудового потенциала предприятия по двойному признаку:

- по среде существования: внешние и внутренние;

- по составляющими воспроизводства: натуральные, стоимостные, социальные.

Данная группировка представлена на рисунке 1.

Выявление основных факторов воспроизводства трудового потенциала, уровня их влияния позволяет наиболее четко сформировать пути повышения его качества, регулировать и развивать в заданном направлении, а также разработать инструментарий оценки трудового потенциала, то есть научно обоснованной системы показателей и способов их фиксирования, в частности, для целей оценки стоимости предприятия. 


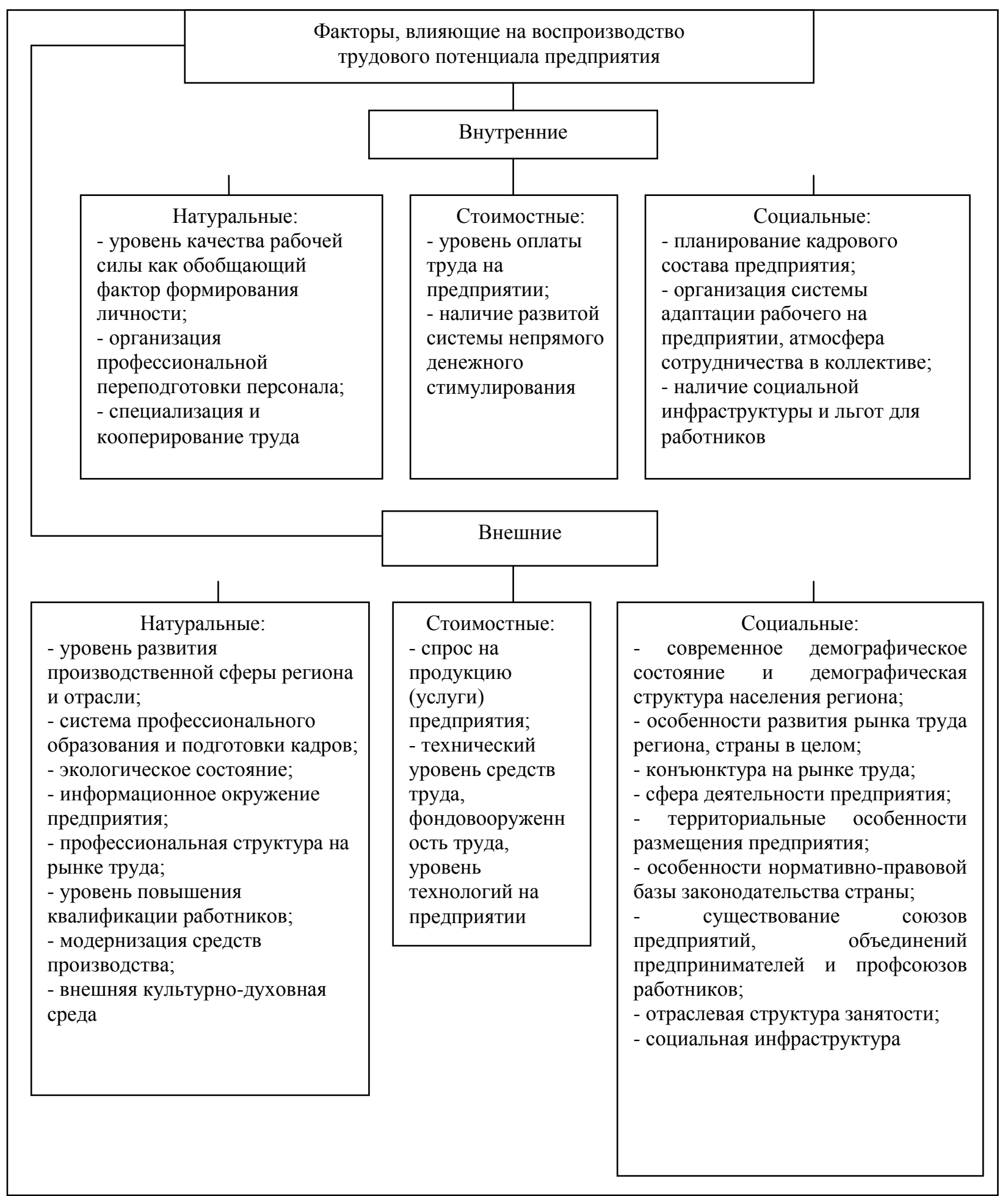

Рисунок 1 - Факторы, влияющие на воспроизводство трудового потенциала предприятия (составлено автором) 


\section{Литература}

1. Административное управление трудовым потенциалом. / Под ред. В. М. Гриньковой.- Х.: ВД «Инжек», 2004.- 336с.

2. Генкин Б.М. Экономика и социология труда.- М.: Норма, 2001.- 448c.

3. Джаин И.О. Оценка трудового потенциала: Монография.- Сумы: ИТД «Университетская книга», 2002.- 250с.

4. Краснокутська Н.С. Потенциал предпринимательства: формирование и оценка: учебн. пособ. - Киев: Центр начальной литературы, 2005.- 352с.

5. Мельник Ю.А. Воспроизводство трудового потенциала предприятия: аспект управления // Бизнесинформ, 2009. - №3. - С.118-123. 